International Journal of Canadian Studies

Revue internationale d'études canadiennes
INTERNATIONAL JOURNAL OF CANADIAN STUDIES

REVUE INTERNATIONALF D'ÉTUDES CANADIENNES

\title{
The Two Souls of the Canadian Charter of Rights and Freedoms
}

\section{Giancarlo Rolla}

Numéro 36, 2007

Democracy, Rule of Law and Human Rights. Canada 25 Years after the Charter of Rights and Freedoms

La démocratie, l’État de droit et les droits de la personne. Le Canada, 25 ans après la Charte des droits et libertés

URI : https://id.erudit.org/iderudit/040789ar

DOI : https://doi.org/10.7202/040789ar

Aller au sommaire du numéro

Éditeur(s)

Conseil international d'études canadiennes

ISSN

1180-3991 (imprimé)

1923-5291 (numérique)

Découvrir la revue

Citer cette note

Rolla, G. (2007). The Two Souls of the Canadian Charter of Rights and Freedoms. International Journal of Canadian Studies / Revue internationale d'études canadiennes, (36), 329-345. https://doi.org/10.7202/040789ar d'utilisation que vous pouvez consulter en ligne. 


\section{Giancarlo Rolla}

\section{The Two Souls of the Canadian Charter of Rights and Freedoms}

\section{Introduction}

It is conventional wisdom that the acknowledgment and the safeguard of rights focusing on the protection and support of the human person are a result of constitutionalism, which rejects absolute government in favour of a system based on the rule of law. Provided that a system based on the rule of law is firmly founded on fundamental human rights, their safeguard and protection play an essential role in defining the essence of democratic legal orders: namely, they represent a condition for their existence. In other words, these rights turn out to be a key factor in the making of a constitutional system, since they contribute, along with other high-ranking principles, to establishing the constitutional values of a democratic country.

An undeniable bond-both historical and cultural in nature-connects all constitutions currently in force to the ideals originating from those past revolutions that led to the recognition of such rights. Even so, plenty of changes have significantly affected the perception of human rights, as well as of their protective measures. Specifically, the most recent bills of rights have unique, distinctive elements, compared with traditional models. In our opinion, the most interesting feature is represented by a new and improved version of the personalism principle.

If it is understood that the human person-together with the relevant need for protection-has always been regarded as the focus of modern constitutions, it is obvious that throughout the shift that moved away from a liberal system based on the rule of law towards a more socio-democratic system, the individualistic concept of the human person was gradually replaced by a more advanced notion, according to which the individual cannot be deemed as an isolated being, but as a participant of society and of community life. As a result, this adjustment in perspective determined an enhancement of the values on which constitutional bills are grounded: in other words, not only freedom and equality are to be considered fundamental, but now also dignity and solidarity must be awarded the same recognition. Therefore, the personalism principle gradually changed, in order to keep up with the system's evolution into a state based on the rule of law. 
In the most long-standing liberal systems, charters acknowledged the existence of a society, where all citizens-in abstract-were considered equal. Also, they mainly regulated those legal institutions aimed at securing individual freedom (especially, habeas corpus, freedom of movement and trade, freedom of religion, private property, and the other so-called freedoms of the first generation). However, the later "welfare state" version of constitutionalism made possible a more socially oriented perception of the human being. As a result, all citizens have now become men and women, actual human beings with their own individuality. This development was achieved in various stages. Initially, all rights relating to the principle of freedom were associated with the principle of equality. Thus, civil rights were linked to both social rights and political rights. The principle of equality was granted constitutional priority, not only in connection with its formal aspect, according to which everyone is equal before the law, but also with respect to its substantial dimension. In fact, given the many actual forms of discrimination in society, public authorities are expected to step in and remove all obstacles that prevent true equality among individuals. As a result of this, social policy and active measures are given constitutional underpinning.

Modern legal orders are increasingly aware that societies are now less homogeneous on account of pervasive economic, social, and political differences. Societies have also become more multiethnic and multicultural. Hence, the recognition of existing differences has become a matter of great interest.

If it is obvious that humanity in general is fascinated by the idea that all people are created equal, it is just as evident that society as a whole brings out existing social differences. When such "non-equalities" are linked with episodes of historically- and socially-based discrimination, or with particular conditions that make some individuals more vulnerable than others, then they must be removed, as they are likely to develop into grounds for discrimination. When, on the contrary, such "non-equalities" have to do with differences that both help to promote personal growth, as well as help to constitute the identity of a group, then they must be deemed positive and pursued accordingly.

Assuming the positive value of differences as the keystone of our argument, it follows that such "non-equalities" have to do with both the private and public aspects of each individual person's life. Indeed, according to Article 2 of the Italian Constitution, "the Republic recognizes and protects the inviolable rights of each person, as an individual as well as a member of any social structure in which one expresses his or her personality." Both the private and communal aspects of human personality are clearly acknowledged in the 1982 Canadian Charter of Rights and Freedoms. Specifically, section 7 recognizes and safeguards the individual and natural degree of personal autonomy in making decisions of 
fundamental personal importance, while section 27 acknowledges personal public involvement in larger social groups, which derive their well-defined individuality from commonly felt and historically reinforced ethnic, linguistic, and cultural factors.

\section{Acknowledging Universally Recognized Rights Together with Cultural Divergences: Conflict within the Canadian Charter of Rights and Freedoms}

The Canadian Charter of Rights and Freedoms tries to expose the "two souls" possessed by each individual at once, in an attempt to bring them together and harmoniously combine them.'

On the one hand, the Charter purports to establish a common platform of rights for all Canadian citizens, while on the other it tries to recognize the importance of Canada's multicultural nature, together with the current existence of indigenous communities holding inherent rights. Therefore, the Charter of Rights and Freedoms concentrates on two different objectives: it aims to guarantee the same rights to every Canadian citizen, but at the same time it also tries to provide constitutional recognition for all ethnic identities living together in Canada's unified society. ${ }^{2}$

Sections 2 to 12 of the Charter list several individual rights, including the freedom of religion, the freedom of expression, the right to assembly, the freedom of association, the right to bodily integrity and personal safety, the right to due process of law, and protection against cruel and unusual punishment. In addition, section 15(1) establishes the principle of non-discriminatory treatment before and under the law, while section 15(2) recognizes the legality of affirmative actions aimed at improving any disadvantageous condition of individuals or groups, should they be founded on race, national or ethnic origin, colour, religion, sex, age, or mental or physical disability.

However, several other sections of the Canada's Constitution Act, 1982 (which includes the Charter) attempt to balance the protection of universally recognized human rights with rights that, instead, are acknowledged exclusively on account of shared cultural identity. This is the case, for example, with section 25 of the Charter and section 35 of the Constitution Act, 1982. These sections, respectively, provide that any pertinent treaty, right, and liberty cannot in any way be abrogated or derogated by way of the Charter and acknowledge the rights of the Aboriginal communities residing in Canada. ${ }^{3}$ In addition, section 27 provides that "this Charter shall be interpreted in a manner consistent with the preservation and enhancement of the multicultural heritage of Canadians." 4 
There are also several general principles aimed at promoting the right balance between universally applicable rights and specific derogations in favour of definite groups: such is the purpose of the Charter's so-called "notwithstanding clause," contained in section 33, and the "reasonable limits" clause, contained in section 1 , which can justify a law that otherwise violates one of the rights guaranteed under the Charter, because that law is acceptable in a "free and democratic society."

On this point, it is worthwhile to call attention to the argument that the free and democratic society clause implies acceptance of the principle of multiculturalism. As Justice Quigley held in a case examining the constitutional validity of Canada's "hate speech" laws, society can be regarded as free and democratic only when it acknowledges the principles of equality and multiculturalism. ${ }^{6}$ Likewise, the protection of the multicultural heritage constitutes a public interest, since racial tolerance is an essential ingredient for the good performance of a free and democratic society. ${ }^{7}$

Further proof of this can be found in the 1989 Report by the Canadian Human Rights Commission. It stated that multiculturalism involves accepting existing differences and in recognizing that such differences are in themselves equal. All ethnic communities represented within Canadian society deserve equal dignity and worth. As a result, these ethical and political claims can be read as an interpretation of the constitutional principle of equality, as seen through the lens reflecting Canada's multicultural nature. ${ }^{8}$ The apparent conflict between the recognition of universally accepted rights and the protection of socio-historical differences has not been the only cause of friction within the Canadian constitutional order. Throughout Canadian history, when the country has been under stress, legislators and judges made a great effort to preserve the nation's stability. This was true during the struggle dividing the federal government and the provinces over their respective boundaries of legislative jurisdiction. The legal system has also been involved in settling differences deriving from historical antagonism between the English-speaking and the French-speaking communities. The latter disputes have resulted in progressively deteriorating interaction between the province of Quebec and the rest of the federation. Lastly, a degree of instability has been caused by economic differences, prompting Western provinces (such as British Columbia and Alberta) to constantly press the politically established and prominent central provinces, Ontario and Quebec, for greater political visibility. The Western provinces' increased economic power comes from the extensive use of their agricultural and natural resources, as well as surging population growth.

As a result of these different reasons, the Canadian Charter of Rights and Freedoms has set out on an ambitious quest: to combine the various elements making up social and institutional pluralism in Canada, in order to 
develop a common federal law applicable to the entire country. According to this approach, then, the Charter of Rights and Freedoms seems to acquire a much greater institutional import and goes beyond the mere cataloguing of rights. It appears to be the keystone on which to build the country's unity, in light of universally recognized values, despite the fact that individuals living within Canada are linguistically, culturally, and economically different. Therefore, the Charter is supposed to serve as a channel for the integration of all social groups settled in different parts of the country.

\section{The Constitutional Recognition of the Right to Freely Express One's Lifestyle}

Keeping in mind the schema introduced at the beginning of this paper, one can view section 7 of the Canadian Charter of Rights and Freedoms as specifically acknowledging the individualistic dimension that shapes each human being. This section provides that "everyone has the right to life, liberty and security of the person and the right not to be deprived thereof except in accordance with the principles of fundamental justice."

The section is difficult to interpret and apply, as illustrated by the contradictory results reached, not only by legal theorists, but also by courts. At the outset, it is crucial to determine whether section 7 represents a procedural or a substantive safeguard. ${ }^{10}$ Should the latter be the chosen assumption, it is then necessary to determine the section's exact intent, thus revealing the precise meaning of the expressions selected.

From the beginning of the Charter era, certain authors regarded section 7 as a procedural safeguard: in other words, it must be construed as the basis for procedural fairness. ${ }^{11}$ Legal commentators employed different arguments to come to this conclusion. First, they considered section 7's strategic placement within the Charter of Rights and Freedoms, where it is in fact the first section of the part relating to legal rights. Also, those authors resorted to a comparative analysis, as well as taking into account the constituent's original intent.

Just as the Fifth Amendment to the U.S. Constitution sanctions that no person shall be deprived of life, liberty or property without due process of law, it followed (for those Canadian authors) that section 7 provides for the abridgement of selected rights (rights to life, liberty, and security), as long as specific procedural safeguards, arising from the due process of law principle, are secured.

Other authors seem to reach similar conclusions, even though their arguments pursue a different route, as they believe it is necessary to interpret the content of the Charter according to the constituent's original intent. In their opinion, based on examining the Charter's travaux préparatoires, the intention was never to confer on section 7 an innovative 
function that would distinguish it from what was stated in the Canadian Bill of Rights of 1960 . Section 2(e) of the 1960 Bill of Rights provided that no law of Canada shall be construed or applied so as to ... deprive a person of the right to a fair hearing in accordance with the principles of fundamental justice for the determination of his rights and obligations. ${ }^{12}$

However, such interpretations of section 7, which restrict its scope to mere procedural fairness, have not been widely accepted. Originalist theories, which are popular in North. America, though not commonly found in European legal literature, seem to ignore that every constitution is a living tree-or "living law," according to the terminology employed by Italian legal theory. As a consequence, once its provisions have entered into force, they become part of the actual legal order, separate from the original legislator's intents. Their meaning is notnecessarily the one assigned by the constitution-drafters, but rather the one that gradually derives from the application of legal principles and interpretative techniques. If this were not the case, the legal order would remain fossilized, and the law could not evolve together with society and customs. As stated by the Supreme Court of Canada in connection with the meaning of section 7 , an evolving interpretation of the law is included in the inherent domain of the judiciary as guardian of the justice system. ${ }^{13}$

In addition, a comparative analysis extending to other constitutions is still not entirely probative, since section 7 differs from section 2(e) of the Canadian Bill of Rights of 1960, as well as from the Fifth Amendment to the U.S. Constitution. Specifically, while those earlier provisions consist of only one clause expressly dealing with a procedural safeguard (i.e., due process of law), the Canadian Charter introduces two separate and independent rights - the right to life, liberty and security, on one hand, and the right not to be deprived thereof except in accordance with the principles of fundamental justice, on the other. As between the two, only the latter can be regarded as possessing an undeniable procedural connotation. By contrast, the importance of the former is purely substantial, in the sense that, even as life, liberty, and security are awarded their own, specific meaning, they simultaneously take part in safeguarding a common legal interest, namely, a special area of human privacy.

In particular, the right to life protects a person through his or her entire course of life, from the moment one is granted legal personality, up until he or she is declared legally dead. ${ }^{14}$ The expression liberty, instead, does not cover only physical freedom (the traditional habeas corpus), but it also includes personal privacy. Specifically, the right to liberty embraces many different expressions of human individuality, which can be summed up in every person's right to freely determine his or her actions, and more precisely, to own a certain degree of autonomy in making decisions of fundamental personal importance, and in particular, a degree of personal 
autonomy over important decisions intimately affecting their private lives. ${ }^{15}$

Such profound autonomy or self-determination can be found, for example, in a woman's right to have control over her body, and therefore, over every stage of her pregnancy. ${ }^{16}$ Also, it can be detected in every individual's right to freely play a role in society, to see the world according to one's own opinion. Similarly, the right to liberty consists in the power to dispose of one's body, even if such right can be limited only as far as public interest will allow. ${ }^{17}$

Lastly, the term security has typically been construed according to the definition provided by the World Health Organization, which recognizes the personal right to a state of complete physical, mental, and social well-being. In other words, the concept of security also refers to both physical and psychological well-being, thus making it possible to infringe on the right to security should a third party interfere with a person's privacy: such behaviour could affect psychological security, causing anxiety, stress, and emotional trauma.

Obviously, section 7 of the Charter cannot be construed to the point of positively recognizing a constitutional right to benefit from the services supplied by a welfare state. It is readily understood that social rights-as they are subject to governmental discretionary power-are not absolute and therefore must be balanced with other constitutional principles and values. However, there is no doubt that by virtue of this constitutional provision, it is illegal for public powers to deprive anyone of a minimum level of economic comfort necessary to satisfy basic needs, because in such a case human dignity would most certainly be compromised. ${ }^{18}$

Even though they are distinct, the three expressions of life, liberty, and security all originate from the more general notion of human dignity. As stated by the Canadian Supreme Court, section 7 involves the right to personal dignity and a right to an area of privacy or individual sovereignty into which the state must not make arbitrary or unjustified intrusions. ${ }^{19}$

The principle by which human dignity has constitutional status allows for a double interpretation of its meaning: the first relates to a more individualistic context, while the second concerns social relations. The former is connected with the right to the respect and protection of one's reputation, that is, of one's good name, reputation and integrity. The latter can exist only if there is a social conscience aimed at preventing unavoidable social differences from being converted into reasons for exclusion or grounds for discrimination. By virtue of such right, it then follows that all persons must be granted the same respect, despite their different social position: in other words, they must be treated as an equal. 
That is, the social environment must provide for relationships inspired by a natural duty of mutual respect. ${ }^{20}$

Likewise, recognizing the equal dignity of groups only represents the other side of the need to prevent social discrimination. As Justice Iacobucci has clearly stated, the rule against discrimination is determined to prevent "the violation of essential human dignity and freedom through the imposition of disadvantage, stereotyping, or political or social prejudice, and to promote a society in which all persons enjoy equal recognition at law as human beings or as members of Canadian society."21

Finally, the principle conferring equal dignity to all persons refers to both the individual, as well as to the group to which he or she belongs. ${ }^{22}$

\section{The Protection of Multiculturalism According to Section 27 of the Canadian Charter of Rights and Freedoms}

Section 27 of the Canadian Charter of Rights and Freedoms includes an interpretative clause, by way of which the legislator may allow exceptions to be made with regard to the universalistic nature of specific rights, as long as said exceptions are reasonable, compliant with the principle of proportionality and aimed at promoting Canada's multifaceted ethnic mosaic. As a result, such provision acknowledges and promotes the country's "multicultural heritage," and indirectly, it also grants members of ethnic, religious, and linguistic groups the right to protect their cultural identity. ${ }^{23}$

Many commentators, however, have criticized the final draft adopted by the drafters of the Charter. While some legal authors have argued that such constitutional clauses are poorly enforceable, as they merely add up to rhetorical flourish, ${ }^{24}$ others have found section 27 problematic because it is difficult to define the exact legal meaning of the expression multicultural heritage..$^{25}$ Moreover, other commentators have drawn attention to the fact that section 27 is more important for its political value, rather than its legal impact, as it was included in the Charter in response to overwhelming pressure put on the government by associations representing different ethnic groups.

Similar to the controversies surrounding the interpretation of section 7 , legal and academic disputes about what is the legal significance of section 27 are tumultuous.

Indeed, there is no doubt that section 27 of the Charter does not list specific rights to cultural identity. On the contrary, it defines multiculturalism as an interpretative principle. In addition, section 27 is not even formally included among those parts of the Charter that establish various rights, but it is included in that "remedial" part that addresses how 
the Charter shall be enforced. Therefore, it keeps company with the interpretation rules set forth by Sections 21, 22, 25, 26 and 29 of the Canadian Charter of Rights and Freedoms. Nevertheless, section 27 is different from all other interpretation principles. First, it fulfills a protective role: it was in fact introduced in order to preserve the delicate institutional balance reached on the matter of aboriginal peoples, as well as of linguistic rights, of education and of multiculturalism. In addition, it has a constructive role, as it supposed to promote the enhancement of the multicultural heritage. Finally, it serves an instructive, though not self-executing, function. In fact it provides constitutional underpinning to the principle according to which Canadian uniqueness is determined by the contribution of several different cultures. In other words, the fact that this article can be listed among interpretation principles does not rule out the possibility of it having a significant impact in protecting multicultural identities and practices.

First of all, section 27 identifies its main beneficiaries, that is, those who are obliged to preserve and enhance the multicultural heritage of Canadians. Courts are most certainly the main target; however, section 27 appears to be intended for other recipients as well, should the Charter's interpretation be considered logically preliminary to its implementation and enforcement.

Consequently, the duty to read the entire Charter according to the principle promoting Canadian multiculturalism must be taken on by the legislator (who must abide by such principle when passing specific laws or formulating general policies), as well as by all public authorities, when discharging their duty to implement supportive action. Indeed, multicultural heritage is a treasure that must be supported and protected against potential cultural assimilation and standardization. In view of this, it is worth noticing that the terms used so far-preserve, enhance - betoken an attitude opposed to the so-called melting pot policy.

However, given its overall regulatory range, section 27 affects all individuals, as all private activities must not get in the way of the main constitutional objective, aimed at achieving the preservation and enhancement of the multicultural heritage of Canadians.

With regard to its focus of attention, section 27 of the Canadian Charter of Rights and Freedoms is an example of a so-called "open clause," which embraces unenumerated and unanticipated referents. In fact, it not only protects the cultural identity of the historically established minorities, but it stretches out to offer the same recognition to all the more recently immigrated communities, namely the "visible minorities." If this interpretation is correct, the constitutional meaning of multicultural "heritage" takes on a totally new dimension, as it applies to all the groups who, now and in the future, join in creating Canada's pluralistic society. It 
suggests their active involvement in the foundation of the country's cultural heritage. This is a modern notion of "population": a continuous process in which individuals alternate and come after each other, generation after generation.

Lastly, the concept of multicultural heritage of Canadians is not necessarily generic, nebulous, and hard to define. First of all, its meaning can be precisely determined by resorting to the connotation it has taken on in the international legal order, especially within the lines of decision of international courts and in international documents on the protection of community identity and ethnic minorities. It is natural, for example, to bring section 27 of the International Covenant on Civil and Political Rights to mind, which indeed recognizes the right of all minority members to enjoy their culture, to profess and practice their religion as well as to speak their language.

Besides; legal commentators can also apply so-called mediating principles, that is, descriptive principles derived from various scientific fields, such as the definition of culture found in Webster's Third New World Dictionary, according to which culture can be considered as "the body of customary belief, social forms and material traits constituting a distinct complex tradition of racial, religious or social group," and also as "that complex whole that includes knowledge, belief, morals, law, customs, opinions, religion, superstition." Other legal authors have instead drawn on sociological studies, according to which cultural heritage is a complex concept that involves the recognition of a rule against group discrimination, the acknowledgement of symbolic ethnicity (namely; the aspirationshared by several individuals - to support the fundamental characteristics that set their identity and personality apart), as well as the recognition of structural ethnicity (that is, the existence of institutions and instruments aimed at protecting the group's stability, as well as preserving its identity against assimilating trends). ${ }^{26}$

Until now, the interpretative principle set forth by section 27 of the Charter of Rights and Freedoms has been used with extreme moderation. It is useful to look closely at the analysis by legal commentators as well as at the decisions of the Supreme Court of Canada.

First of all, the Courts have employed the multicultural principle in an identifying effort, in order to define the scope and substance of several rights, especially of those specifically protected under section 2 of the Charter.

With regard to religious freedom, section 27 corroborated the argument according to which a provision establishing Sunday as a holiday was discriminatory towards non-Christian religions and violated the duty to protect Canadians' multicultural heritage. ${ }^{27}$ Likewise, another case 
revealed a similar approach, as the court stated that the support given to one element of the population of Canada by the Lord's Day Act is an unacceptable preference by the state for the religious beliefs of some Christians. ${ }^{28}$

By contrast, the approach followed in connection with a province's Retail Business Act, which regulates which commercial activities could operate on Sundays, was quite different. In this context, the Supreme Court held that the multicultural principle did not authorize a Jewish storekeeper to do business on Sundays, even if the store had been closed on Saturday, as it disregarded the rules established by the Retail Business Act. $^{29}$

In a recent ruling, the Supreme Court was compelled to balance the security interests of the students and school staff with religious freedom. Even if it did not expressly refer to the multicultural clause established by section 27 of the Charter of Rights and Freedoms, it did however allude to the multicultural principle, as it held that the total prohibition for Sikh students to wear the kirpan at school could not be regarded as one of the instances sanctioned by Section 1 .

On this matter, it is worth mentioning that the court justified its decision not to apply the said section for two different reasons: on one hand, it considered the measures chosen to limit religious freedom as not proportionate to the pursued objective, on the other it held that "a total prohibition against wearing a Kirpan to school undermines the value of this religious symbol and sends students the message that some religious practices do not merit the same protection as others." Consequently, the said message would ultimately question some of the very basic values upon which Canadian democracy and society are based, such as religious tolerance, respect for minorities, and multiculturalism. ${ }^{30}$

Section 27 has also been employed by the Supreme Court in order to better define one's right to an interpreter during litigation. Specifically, the Court held that it would be discriminatory to restrict the interpreter from translating the entire civil proceedings, by using the defendant's mother tongue, whenever the defendant is a citizen of a different race and is unable to understand English. ${ }^{31}$

Conversely, the Supreme Court did not regard section 27 as necessarily applicable in connection with the privileges awarded to certain religious groups, particularly with regards to educational issues. In fact, the court maintained that the multicultural principle could not have any effect on the exceptional provision contained in section 29 of the Charter, which, by derogating from the equality principle, protects the rights and privileges recognized to denominational, separate, or dissentient schools. In particular, the court held that the favourable treatment protected by section 
29 could be regarded as one of the factors establishing the institutional compromise on which the Canadian federation is founded. ${ }^{32}$

Although that opinion reflects the current Supreme Court doctrine, it has not won over all the judges on the court: a dissenting opinion claimed in fact that denying public funding to the schools belonging to minority religious groups is not simply economically detrimental, but it is also disadvantageous to the strengthening of one's own faith and multicultural heritage.

By the same token, section 27 is ever more significant in connection with the anti-discrimination rule established by section 15(1) of the Charter. On the one hand, this provision must be read with the purpose of promoting the development of multicultural values. On the other, such values cannot be used as an excuse to encourage a discriminatory attitude towards other groups or individuals. For example, if the decision to finance positive actions in favour of cultural groups were approved, it would then be discriminatory to adopt rules that did not offer equal opportunities to all of them. Likewise, it would be discriminatory to adopt a piece of legislation that does not supply all ethnic groups with identical access to public services.

On this matter, the Supreme Court pointed out that safeguarding multiculturalism requires prohibiting any kind of discrimination, even though indirect, and consequently it requested careful consideration of the effect that each rule has on the groups shaping Canada's ethnic mosaic. The court concluded that even unintended consequences determined by a specific rule can end up creating a case of discrimination. ${ }^{33}$

Secondly, if one plate of the balance scale holds the principle of equality established by section 15 of the Charter of Rights and Freedoms, the other one must be occupied by the multicultural principle, so as to avoid that the possibility that both the legislator and the courts take "equality" to mean uniformity and homogeneity. As a result, these two principles establish a rule against difference in treatment and positive actions, should the said measures favour certain ethnic groups only.

According to many commentators, combining the equality principle together with the multicultural principle rules out the possibility of adopting "assimilation" policy choices, as well as melting pot theories. It follows that section 27 substantiates the use of rules derogating from the equality principle. For example, even though teachers should be appointed on a merit basis, there is no constitutional prohibition for provisions that allow appointing them on the premise that a certain ethnic quota must be assured among the teaching personnel, given the unique, social environment in which the school operates. On the other hand, the Supreme Court has held that all issues having to do with culture hold a reinforcing 
connotation, given that they have been awarded specific constitutional recognition. ${ }^{34}$

Pointing this out is key for the management of modern, complex, and multiracial societies. Recognizing cultural diversity in these legal orders must be properly balanced and regulated in an attempt to ensure that each individual leads a peaceful and tolerant existence within society. In this way, the pluralistic perception of cultural groups comes to represent a reason for criticism towards a more liberal and more individualistic version of the equality principle: as one legal writer rightly stated, cultural equality goes through the recognition of cultural pluralism. ${ }^{35}$

At the moment, however, the Supreme Court has not adopted the view according to which the multicultural heritage interpretative rule can act as a limitation on the exercise of freedom of expression, especially in cases of campaigns furthering racial or group hate. The court believes that freedom of expression constitutes a universally recognized right regardless of whether the cultural messages are truly acceptable. Therefore, the court held that punishing a teacher who had talked to his classroom about racist beliefs was unconstitutional, ${ }^{36}$ as was punishing a writer who, having denied in his book that the Holocaust had ever taken place, had been accused of spreading untruthful facts. ${ }^{37}$

In this instance, however, it is important to take into account the dissenting opinion that was submitted by some of the Justices. They claimed that the limitation clause defending a free and democratic society was applicable to the case at issue, in light of the fact that racial tolerance is essential to a democratic society.

\section{Conclusion}

Given their role as pact between the citizens and the territories, charters are called on to create a common foundation of values, thus promoting a sense of belonging to the same political community. In pluralistic and multicultural societies, the said result may be achieved only by acknowledging both the traditional values pertaining to individual freedom, as well as the many and diverse values brought forth due to the multicultural nature of the country. To this purpose, the recognition of general rights - acknowledged by all Canadians "from coast to coast"-must be accompanied also by specific interpretation clauses, established for the protection and advancement of the various identities living within the same society.

In so doing, the Canadian Charter of Rights and Freedoms takes into consideration both its past (that is, the inherent rights of Aboriginal groups), as well as its future (namely, the ethnic mosaic, in which several ethnic communities coexist). The Charter, however, also respects the "two souls" 
that join together in making up modern human persons: that is, the individualistic identity and the group-belonging identity.

For this reason, section 7 of the Charter should be construed together with section 27 , in light of the fact that the former promotes the free development of human personality, while the latter acknowledges and enhances the various; multiple differences that make Canada a home of diverse communities. In between these sections and acting as balancing bar is section 15, which codifies the principle of equality: on one hand, it rules out any discriminatory consequences for individuals and for groups, while on the other it guarantees equal dignity to all human persons and to all groups.

However today, 25 years after its adoption, the role played by the Canadian Charter of Rights and Freedoms with regard to the democratic development of Canadian society cannot be fully understood without taking into consideration the Supreme Court rulings. Specifically, the court holds the merit of having liberally interpreted and enthusiastically applied the Charter, thus indeed transforming it into a living tree, "capable of growth and development over time to meet new social, political, and historical realities often unimagined by its framers."

From this perspective, the Supreme Court has truly been able to steer the development of the Canadian society and of its institutions, gliding through a river in which the two shores are represented by the values upheld by a modern, liberal and democratic society: namely, a high degree of personal autonomy, equal dignity to all people, cultural and identity pluralism, social relations based on tolerance, and a natural duty of mutual respect. ${ }^{38}$

\section{Notes}

1. On the matter of constitutional protection of rights in Canada, please refer to: Rolla, G., Lo sviluppo dei diritti fondamentali in Canada, Milano, 2000; Tarnopolsky, W., \& Beaudoin, A., The Canadian Charter of Rights and Freedoms, Toronto, 1982.

2. An overview of the main steps taken towards the passing of the 1982 Constitution Act can be found in AA.VV., L'ordinamento constituzionale del Canada Torino, 1997; Russell, P., Constitutional Odyssey, Toronto, 1992; Knopff, R., \& T. Morton, Charter Politics, Toronto, 1992; Tarnopolsky, W., \& A. Beaudoin, The Canadian Charter of Rights and Freedoms, Toronto, 1982; Hogg, P., Constitutional Law of Canada, Toronto, 1985; Morton, T., "The Political Impact of the Canadian Charter of Rights and Freedoms," Canadian Journal of Political Science, 1987, 31 ss. The difficult process leading to the completion of the Canadian constitutional order is examined, among others, by: AA.VV., Constitutional Predicament, Montreal, 1994; Caims, A., Constitutional Struggle from the Charter to Meech Lake, Toronto, 1991; Monahan, P., The Inside History, Toronto, 1991; Russell, P., Constitutional Odyssey, Toronto, 1002; McRoberts, 
K., \& P. Monahan, The Charlottetown Accord, the Referendum and the Future of Canada, Toronto, 1993.

3. With regard to the Canadian legal theory on the matter of collective rights, please consult: Cardinal, L., "Collective Rights in Canada: A Critical and Bibliographical Study," National Journal of Constitutional Law, 2001, 165; Fremont, J., "Taking Group Rights Seriously," in Magnusson, N., \& A. Soberman, Canadian Constitutional Dilemmas Revisited, Kingston, 1997.

4. On the issue, refer to: Beckton, C., "Section 27 and Section 15 of the Charter," in Multiculturalism and the Charter, Toronto, 1987; Bottos, D., "Multiculturalism: Section 27's Application in Charter," Alberta Journal, 1977, 169; Gibson, D., "Section 27 of the Charter: More than a 'Rhetorical Flourish,"' Alberta Law Review, 1990, 590; Tran, N., "The Canadian Charter of Rights and Freedoms: Justification, Methods and Limits of a Multicultural Interpretation," Columbia Human Rights Law Review, 1996, 37.

5. In order to properly construe the meaning of the free and democratic clause, it is hard to disregard the opinion of Chief Justice Dickson. The Dickson theory is grounded in Regina v. Oakes (1986), which supplied legal commentators with a new test, to be employed when assessing the legitimacy of any law restricting rights sanctioned in the Charter. First of all, it is necessary to determine if and which actual circumstances hinder one's personal exercise to a right, in a way deemed prejudicial to the achievement of fundamental, common objectives; subsequently, the test examines whether the means employed by the law are proportionate to said objectives. Justice Dickson did not intend to make a conclusive list of the potentially worthy social objectives; rather, more as an example, he did identify respect for cultural identity, as well as for group individuality, as valuable goals.

6. R. v. Keegstra, 1990.

7. R. v. Zundel, 1992.

8. With regard to Canada's policy on the matter of multiculturalism, please see: Caims, A. \& C. Williams, The Politics of Gender, Ethnicity and Language in Canada, Toronto, 1986; Cairns, A., "Constitutional Minoritarism in Canada," in Watts-Brown, Canada: The State of the Federation, Kingston, 1990, p. 78; Cairns, A., Reconfigurations: Canadian Citizenship and Constitutional Change, Toronto, 1995; Watts, R.L., Multicultural Societies and Federalism, Ottawa, 1970; AA.VV., Multiculturalism and The Charter: A Legal Perspective, Toronto, 1987; AA.VV., Multiculturalism and the Government of Canada, Ottawa, 1984; S. Sugunasiri, Towards Multicultural Growth, Toronto, 2001; Megyery, K., Ethno-cultural Groups and Visible Minorities in Canadian Politics: The Question of Access, Toronto, 1991; Kymlicka, W., The Rights of Minority Cultures, Oxford, 1995; Kymlicka, W., Multicultural Citizenship, Oxford, 1996; Leonard, E., Multiculturalism in Canada: Challenges and Changes, Scarborough, 1992; Hudson, M., Multiculturalism and the Charter, Toronto, 1987; Day, J.F., Multiculturalism and the History of Canadian Diversity, Toronto, 2000; Brotz, H., "Multiculturalism in Canada: A Model," Canadian Public Policy, 1980, 41; Berry, J., \& J.A. Laponce, Ethnicity and Culture in Canada: The Research Landscape, Toronto, 1994.

9. Christian, T., "Section 7 of the Charter,"Alberta Law Review, 1984, 223; Cohen, J., Regulating Intimacy: A New Legal Paradigm, Princeton, 2002; Colvin, E., "Section 7 of the Charter," Canadian Bar Review, 1989, 560; Garant, P., "Fundamental Rights and Fundamental Justice," in A. Beaudoin \& Ed Ratushny, The Canadian Charter of Rights and Freedoms, Toronto, 1989, 331; Hogg, P., 
Constitutional Law of Canada, Toronto, 1997, 1064; Johnstone, I., "Section 7 of the Charter and Constitutionally Protected Welfare," University of Toronto Faculty of Law Review, 1988, 1; Lee, T., "Section 7 of the Charter: An Overview, "University of Toronto Faculty of Law Review, 1985, 1; Long, R., Rights to Privacy, New York, 1997; Whyte, J., "Fundamental Justice: The Scope and Application of Section 7," Manitoba Law Journal, 1983, 455.

10. A noteworthy use of Section 7 of the Charter of Rights and Freedoms in its function as procedural fairness can be detected in a recent ruling by the Supreme Court (Charkaoui v. Canada [Citizenship and Immigration], 2007). The Court held that the procedures implemented pursuant to the Immigration and Refugee Protection Act 2001 for the protection of citizens against the dangers of terrorism were "fundamentally unfair" and "did not conform to fundamental justice."

11. Hogg, P., Constitutional Law of Canada, Toronto, 1997, 1064.

12. Stephens, M., "Fidelity to Fundamental Justice: An Originalist Construction of Section 7 of the Canadian Charter of Rights and Freedoms," National Journal of Constitutional Law, 2002, 183.

13. Re Motor Vehicle Act, 1985.

14. Strayer, B., "Life under the Canadian Charter: Adjusting the Balance between Legislatures and Courts," Public Law, 1988, 367.

15. Aldeman, E., The Right to Privacy, New York, 1995; McWirther, D., Privacy as a Constitutional Right, New York, 1992; McNaim, C., Privacy Law in Canada, Toronto, 2001.

16. Morgentaler, 1988.

17. Rodriguez v. British Columbia, 1993.

18. Singh v. Minister of Employment and Immigration, 1985.

19. Re R.L. Crain and Couture, 1984.

20. Mendes, E., "Taking Equality into the 21st Century: Establishing the Concept of Equal Human Dignity," National Journal of Constitutional Law, 2000-2001, 3.

21. Law Canada v. Minister of Employment and Immigration, 1999.

22. Eldridge v. Att. Gen. of B.C. and B.C. Medical Services Commission, 1997.

23. On multiculturalism in Canada, please refer to: AA.VV., Multiculturalism and the Charter, Toronto, 1987; Abu Laban, Y., \& T. Nieguth, "Reconsidering the Constitution, Minorities and Politics in Canada," Canadian Journal of Political Science, 2000, 465; AA.VV., Multiculturalism and the Charter: A Legal Perspective, Toronto, 1987; AA.VV., Multiculturalism and the Government of Canada, Ottawa, 1984; Berry, J., \& J.A. LAPONCE, Ethnicity and Culture in Canada: The Research Landscape, Toronto, 1994; Bissoondath, N., \& L. Xiaoping, "Selling Illusions: The Cult of Multiculturalism in Canada," Journal of Canadian Studies, 1995, 130; Cairns, A., Citizenship, Diversity and Pluralism: Canadian and Comparative Perspectives, Montreal, 1999; Dare, W., "Beyond General Pronouncements: A Judicial Approach to Section 27 of the Charter," Alberta Law Review, 1995, 569; Day, J.F., Multiculturalism and the History of Canadian Diversity, Toronto, 2000; Hudson, M., Multiculturalism and the Charter, Toronto, 1987; Leonard, E., Multiculturalism in Canada: Challenges and Changes, Scarborough, 1992; Megyery, K., Ethno-cultural Groups and Visible Minorities in Canadian Politics: The Question of Access, Toronto, 1991; Raynard, S., National Identity in Canada an Cosmopolitan Community, Ottawa, 1997; Watts, R.L., Multicultural Societies and Federalism, Ottawa, 1970; Kymlika, W., Multicultural Citizenship: A Liberal Theory of Minority Rights, Oxford, 1995; The Rights of Minority Cultures, Oxford, 1995; Multicultural Citizenship, Oxford, 1996; Satzewich, V., Deconstructing a Nation: 
Immigration, Multiculturalism and Racism in the 90s Canada, Halifax, 1993; Toope, S., "Cultural Diversity and Human Rights," McGill Law Journal, 1977, 169. For further investigation on the presence of minority groups within the Canadian territory, please see Ceccherini, E., "Diritti individuali v. diritti comunitari," in Rolla, G., Lo sviluppo dei diritti fondamentali in Canada, Milano, 2000.

24. On the matter, refer to Hogg, P., Constitutional Law of Canada, Toronto, 1985.

25. See Brotz, H., "Multiculturalism in Canada: A Model," Canadian Public Policy, $1980,41$.

26. On the matter, please refer to: Magnet, J., "Multiculturalism and Collective Rights: Approach to Section 27," in Beaudoin-Mendes, The Canadian Charter of Rights and Freedoms, Montreal, 1996, 1032.

27. R. v. Big M Drug Mart, 1985.

28. R. v. W.H. Smith Ltd., 1983.

29. R. v. Edward Books and Art, 1986.

30. Multani v. Commission scolaire Marguerite-Bourgeoys, 2006.

31. R. v. Tran, 1994.

32. Adler v. Ontario, 1996.

33. Canadian National Railways v. Bhinder, 1985.

34. Andrews v. Law Society of British Columbia, 1989.

35. Eisemberg, A., "Two Types of Pluralism in Canada," in H. Lazar \& T. McIntosh, How Canadians Connect, Montreal, 1999.

36. R. v. Keegstra, 1990.

37. R. v. Zundel, 1992.

38. On the matter, refer to: Rolla, G. (ed.), Eguali, ma diversi. Identità ed autonomia secondo la giurisprudenza della Corte Suprema del Canada, Milano, 2006. 